\title{
Local Modulation of Host pH by Colletotrichum Species as a Mechanism to Increase Virulence
}

\author{
Dov Prusky, ${ }^{1,2}$ James L. McEvoy, ${ }^{1}$ Britta Leverentz, ${ }^{1}$ and William S. Conway ${ }^{1}$ \\ ${ }^{1}$ Produce Quality and Safety Laboratory, Henry A. Wallace Beltsville Agricultural Research Center, \\ Agricultural Research Service, U.S. Department of Agriculture, Beltsville, MD 20705, U.S.A.; \\ ${ }^{2}$ Department of Postharvest Science of Fresh Produce, Institute for Technology and Storage of \\ Agricultural Products, The Volcani Center, Agricultural Research Organization, P. O. Box 6, Bet Dagan \\ 50250, Israel
}

Submitted 30 March 2001; Accepted 5 June 2001.

The phytopathogenic fungus Colletotrichum gloeosporioides produces one pectate lyase (PL) that is a key virulence factor in disease development. During growth of $C$. gloeosporioides, Colletotrichum acutatum, and Colletotrichum coccodes in acidified yeast extract medium, the fungus secreted ammonia and increased the medium $\mathrm{pH}$. Ammonia accumulation and the consequent $\mathrm{pH}$ change increased as a function of initial $\mathrm{pH}$ and buffer capacity of the medium. PL secretion by $C$. gloeosporioides correspondingly increased as the $\mathrm{pH}$ of the medium increased. The $C$. gloeosporioides pelB gene-disrupted mutant was able to increase ammonia accumulation and $\mathrm{pH}$ of the media similarly to the wild-type isolate. $C$. gloeosporioides in avocado, $C$. coccodes in tomato, and $C$. acutatum in apple showed ammonia accumulation in the infected area where pH increased to 7.5 to 8 and PL activity is optima. In nonhost interactions where $C$. gloeosporioides was inoculated in apples, the addition of ammonia-releasing compounds significantly enhanced pathogenicity to levels similar to those caused by the compatible $C$. acutatumapple interaction. The results therefore suggest the importance of ammonia secretion as a virulence factor, enhancing environmental $\mathrm{pH}$ and pathogenicity of the Colletotrichum species.

Resistance of unripe fruits to Colletotrichum spp. quiescent infections depends on i) the presence of preformed antifungal compounds that decline in ripening fruits, ii) inducible antifungal compounds, and iii) the lack of activation of fungal pathogenicity factors during fruit ripening (Prusky 1996). Significant data suggests the importance of preformed and inducible antifungal compounds in fruits (Prusky 1996; Prusky and Keen 1993). Few reports have described the possibility that fruit resistance to fungal attack is dependent upon

Corresponding author: D. Prusky;. Telephone: +972 3968 3880; Fax: +972 3968 3622; E-mail: prusky33@ netvision.net.il

This article is in the public domain and not copyrightable. It may be freely reprinted with customary crediting of the source. The American Phytopathological Society, 2001. the lack of activation of fungal pathogenicity factors (Prusky 1996), including pectolytic enzymes responsible for maceration of the plant cell wall leading to decay. The inhibition of pathogenicity factor production might be the result of direct inhibition by specific inhibitors such as polygalacturonaseinhibiting protein (Benhamou 1996) and phenols (Wattad et al. 1994), which inhibit fungal attacks during specific periods of fruit development. Yakoby et al. (2000) suggested that the absence of fungal colonization also might depend on inhibiting the secretion of a specific enzyme involved in virulence.

Pectate lyase (PL) from Colletotrichum gloeosporioides is secreted at $\mathrm{pH}$ values higher than 5.8 , but pelB was already expressed at $\mathrm{pH}$ values of 5.1 (Yakoby et al. 2000). The differential timing of pelB expression and PL secretion suggests that PL is translated, but the protein remains in the mycelium until a secretion-permissive $\mathrm{pH}$ level is reached. Additionally, PL was not secreted if the medium was adjusted to $\mathrm{pH}$ levels lower than 5.7. When mycelium grown in pectolytic-inducing media (PEIM) at $\mathrm{pH} 6.5$ was transferred to fresh PEIM at a $\mathrm{pH}$ lower than 5.7, no PL secretion was detected. The lack of PL secretion in PEIM at low $\mathrm{pH}$, following the transfer of mycelium from conditions where PL was being secreted, further supports the regulation of PL secretion by a $\mathrm{pH}$ dependent mechanism.

$\mathrm{pH}$ affects a series of regulatory processes in fungi and yeast (De Bernardis et al. 1998; Denison 2000; Espeso et al. 1993; Keller et al. 1997; Macheroni et al. 1997; Muhlschlegel and Fonzi 1997; Orejas et al. 1995; Otero and Gaillardin 1996; St. Leger et al. 1999). Regulation of genes encoding extracellular enzymes by ambient $\mathrm{pH}$ is useful for fungi such as Aspergillus nidulans, which can grow over a wide $\mathrm{pH}$ level of 2.5 to 9.0. Such a $\mathrm{pH}$ regulation system ensures that extracellular enzymes, permeases, and other exported metabolites are produced under $\mathrm{pH}$ conditions where they can function (Denison 2000). The natural increase of host $\mathrm{pH}$ during fruit ripening regulates $p e l \mathrm{~B}$ expression and $\mathrm{PL}$ secretion by C. gloeosporioides in avocado fruits. Our findings indicate, however, that host environmental $\mathrm{pH}$ also is influenced directly by the pathogen. In the present report, we describe the capability of the Colletotrichum species to secrete ammonia locally into the host tissue, resulting in a $\mathrm{pH}$ increase that enables enzymatic secretion and enhanced virulence. 


\section{RESULTS}

pH changes induced by Colletotrichum species

during growth in the presence of yeast extract.

Growth of $C$. gloeosporioides on $1 \%$ yeast extract solid medium increased the $\mathrm{pH}$ from 4.5 to 5.8 , as detected by the change of Alizarin red $\mathrm{S}$ dye from yellow to red and direct $\mathrm{pH}$ measurement of the medium (Fig. 1). C. acutatum and C. coccodes increased $\mathrm{pH}$ of the medium several millimeters out from the leading edge of the colony, similar to C. gloeosporioides (results not shown). A pelB gene-disrupted mutant
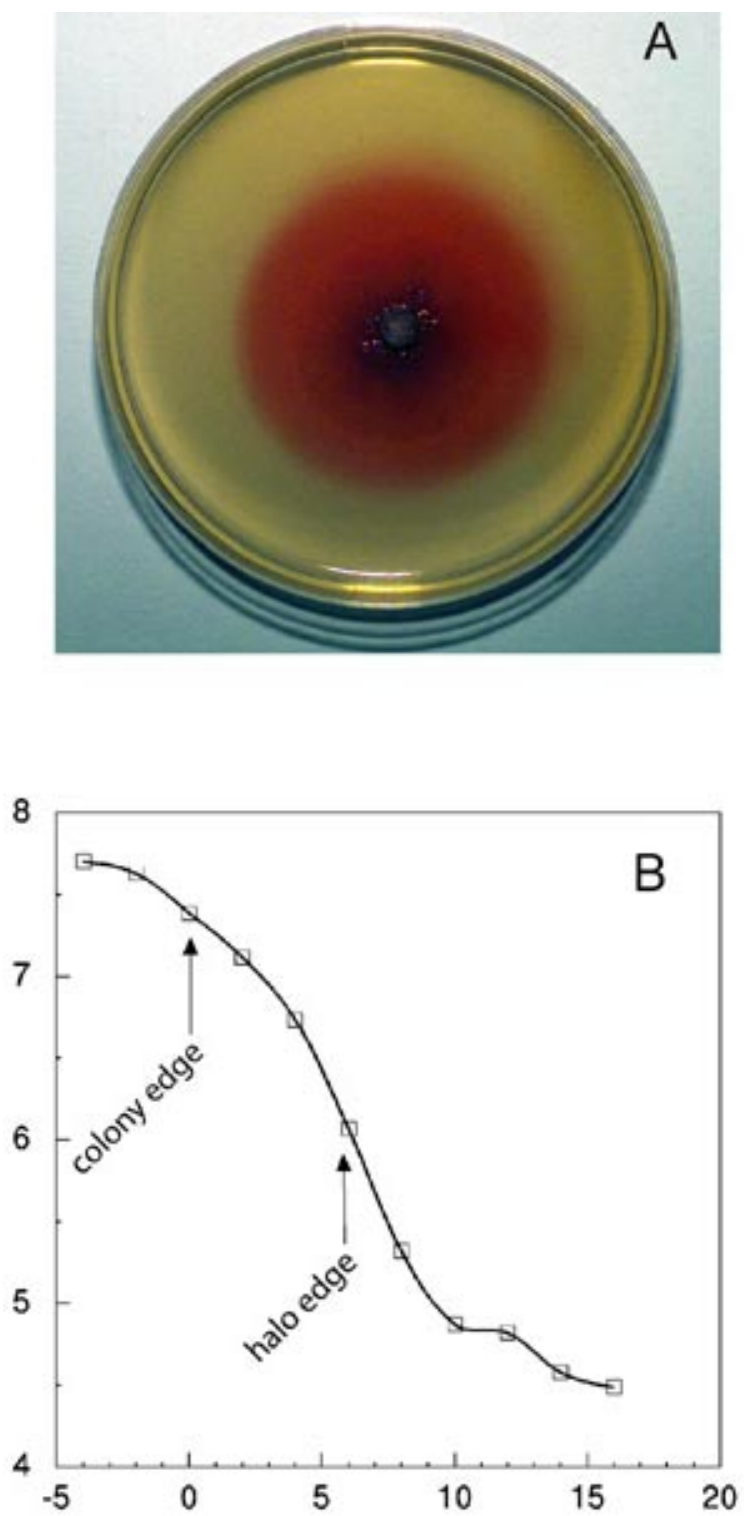

Distance From Edge of Colony $(\mathrm{mm})$

Fig. 1. pH increase induced by Colletotrichum gloeosporioides on acidified yeast extract medium. A, Yeast extract plates at $\mathrm{pH} 4.0$ were inoculated with C. gloeosporioides, incubated at $25^{\circ} \mathrm{C}$ for 5 days, then the plates were stained with $0.2 \%$ Alizarin red $\mathrm{S}$ to determine $\mathrm{pH}$ change. $\mathrm{pH}$ higher than 6.0 was indicated by red, whereas a $\mathrm{pH}$ of 4.0 or less was indicated by yellow. $\mathbf{B}$, Direct $\mathrm{pH}$ measurements on the growth plate. induced the same $\mathrm{pH}$ changes as the wild-type isolate of $C$. gloeosporioides (result not shown).

\section{Induced increase of ammonia and pH}

in yeast extract medium by $C$. acutatum, C. gloeosporioides, and the pelB gene-disrupted mutant.

$C$. acutatum and $C$. gloeosporioides increased ammonia concentration in yeast extract medium, at $40 \mathrm{~h}$ postinoculation, to $6,000 \mu \mathrm{mol}$ per $\mathrm{g}$ of dry weight. It increased, $11 \mathrm{~h}$ later, to $12,000 \mu \mathrm{mol}$ per $\mathrm{g}$ of dry weight (Fig. 2). Ammonia production by both Colletotrichum strains was closely related to fungal growth (Fig 3A). A significant increase, from 0 to $6,000 \mu \mathrm{mol}$ per $\mathrm{g}$ of dry weight, in ammonia corresponded to an increase in $\mathrm{pH}$ from 4.0 to 5.0. Following that breakpoint, the $\mathrm{pH}$ increased by $1 \mathrm{U}$ for approximately $1,500 \mu \mathrm{mol}$ per $\mathrm{g}$ of dry weight of ammonia accumulated (Fig. 3B). The pelB gene-disrupted mutant induced an increase in ammonia, and the corresponding increase in $\mathrm{pH}$ of the media was similar to the wild type $C$. gloeosporioides (results not shown).

\section{Initial pH and buffer concentration} affects ammonia accumulation and induction of $\mathrm{pH}$ changes by $C$. gloeosporioides.

To determine the effect of the initial $\mathrm{pH}$ on the induction of $\mathrm{pH}$ changes and ammonia production, C. gloeosporioides was grown in ammonia-noninducing medium $\mathrm{M}_{3} \mathrm{~S}$ for 3 days, then exposed to the inducing acidified yeast extract medium. In the presence of $50 \mu \mathrm{M}$ phthalate buffer and an initial $\mathrm{pH}$ of 6.2 , the growth of $C$. gloeosporioides for $40 \mathrm{~h}$ resulted in an ammonia accumulation of $1,050 \mu \mathrm{mol}$ per $\mathrm{g}$ of fungal dry weight and a $\mathrm{pH}$ increase to 7.2 (Fig. 4). In the uninoculated acidified yeast extract medium, the ammonia concentration was 1,000 times lower. The $\mathrm{pH}$ level induced by $C$. gloeosporioides in a similar buffer concentration $(50 \mu \mathrm{M}$ phthalate buffer $)$

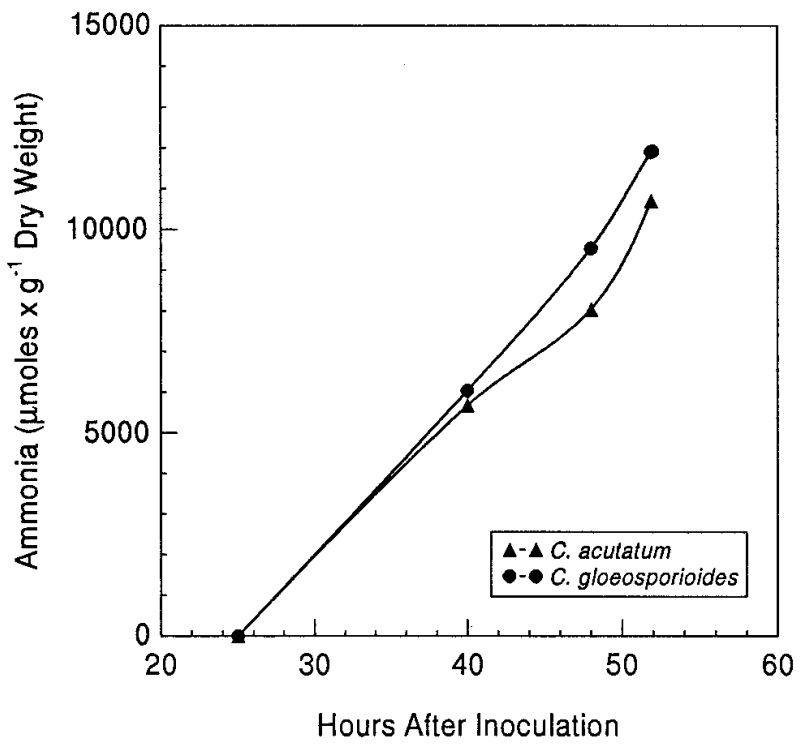

Fig. 2. Accumulation of ammonia in acidified yeast extract liquid medium used to grow Colletotrichum gloeosporioides and Colletotrichum acutatum. 
but at an initial pH of 4.2 was only up to 4.8 . The ammonia accumulation increased only to $400 \mu$ mol per g of dry weight. If $C$. gloeosporioides was transferred to medium containing phthalate buffer at a similar low $\mathrm{pH}$ of 4.2 but at lower concentrations of 10 and $5 \mu \mathrm{M}$, ammonia accumulated and the $\mathrm{pH}$ increased as the buffer concentration declined. PL secretion into the medium containing $50 \mu \mathrm{M}$ phthalate buffer was highest when the initial $\mathrm{pH}$ of the inducing medium was 6.2 , whereas no secretion was observed at $\mathrm{pH}$ 4.2. As the concentration of the phthalate buffer decreased to 10 and $5 \mu \mathrm{M}$ and the final $\mathrm{pH}$ of the medium increased, PL secretion increased as well.
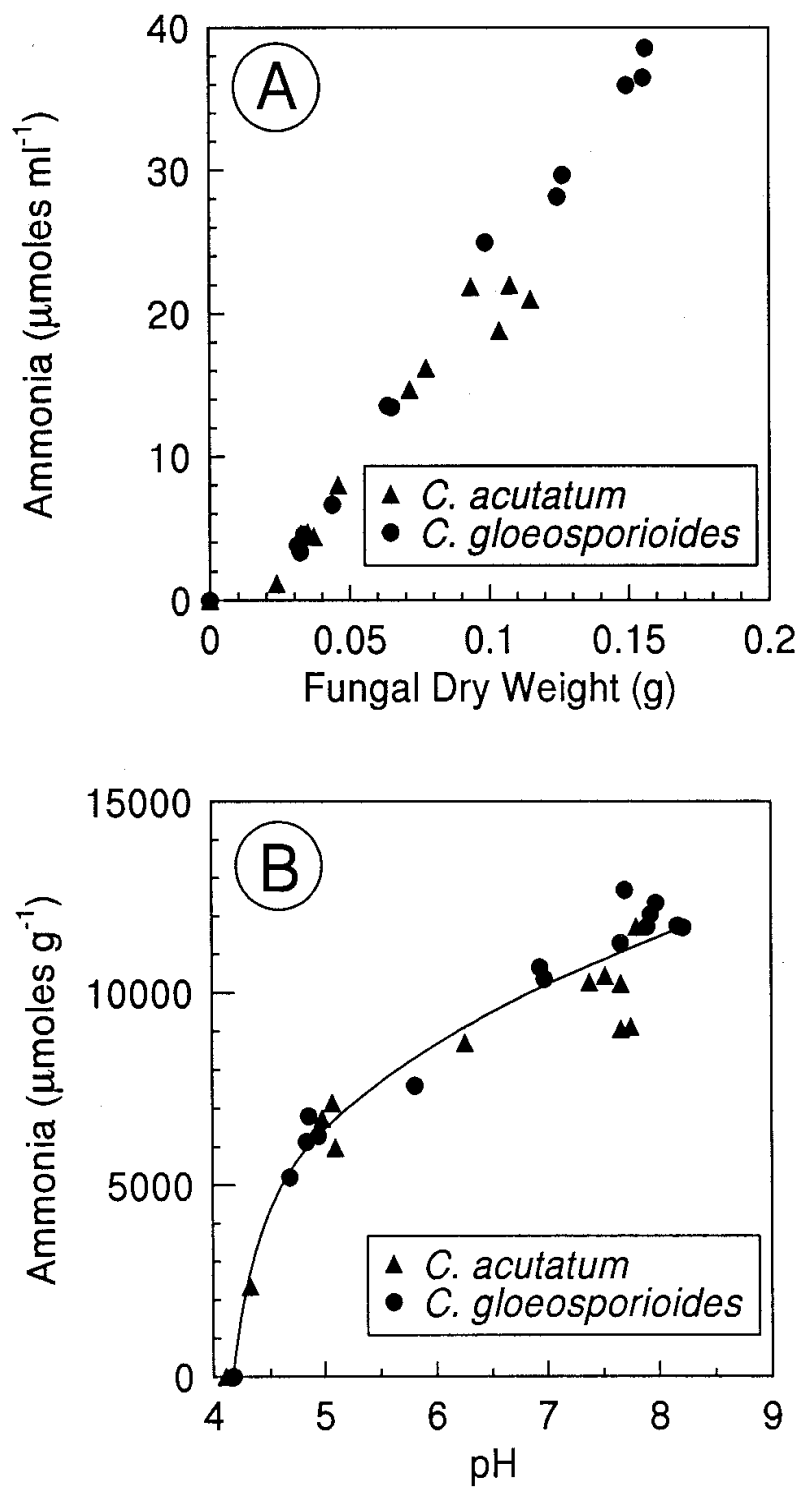

Fig. 3. Relationship between growth, ammonia accumulation, and $\mathrm{pH}$ changes in cultures of Colletotrichum gloeosporioides and Colletotrichum acutatum. Acidified yeast extract was inoculated with $C$. gloeosporioides and C. acutatum. Ammonia concentration, $\mathrm{pH}$, and fungal dry weight were determined at various intervals. A, Relationship between the dry weight of Colletotrichum species and ammonia production. B, Relationship between ammonia production and $\mathrm{pH}$ changes.
Ammonia concentrations and $\mathrm{pH}$ changes induced by the avocado pathogen $C$. gloeosporioides and the tomato pathogen $C$. coccodes.

C. gloeosporioides isolate $\mathrm{Cg}-14$ decayed ripe avocado fruits within 4 days of fruit ripening. Direct $\mathrm{pH}$ measurements in the healthy part outside of the decayed mesocarp tissue showed $\mathrm{pH}$ values of 6.5 to 6.7 (Fig. 5A). In the center or at the edge of the decayed tissue, however, the $\mathrm{pH}$ values were about 7.0 to 7.2. The concentration of ammonia in the extract from healthy avocado mesocarp was $550 \mu \mathrm{M}$, with a $\mathrm{pH}$ value of 6.9 , whereas in the decayed part, ammonia concentration reached 3,350 $\mu \mathrm{M}$, with a $\mathrm{pH}$ of 8.5 (Fig. 5B). Avocado fruits infected with $C$. acutatum also showed characteristic symptoms of decay with a $\mathrm{pH}$ increase to 8.2 and an ammonia concentration of $1,025 \mu \mathrm{M}$ (results not shown). C. coccodes caused significant decay development on ripe tomato fruits within 5 days. Direct $\mathrm{pH}$ measurements of healthy tomato pericarp tissue (OE and $\mathrm{OH}$ in Fig. 6A) showed $\mathrm{pH}$ values of 5.1 to 5.5 . The $\mathrm{pH}$ in the center or the edge of the decayed area (DC and DE in Fig. 6A), however, was approximately 8.0. The concentration of ammonia in the healthy tomato pericarp was $300 \mu \mathrm{M}$, with a $\mathrm{pH}$ value of 4.5 , whereas in the decayed portion, the concentration of ammonia reached $3,600 \mu \mathrm{M}$, with a $\mathrm{pH}$ of 8.6 (Fig. 6B).

\section{Ammonia concentration and $\mathrm{pH}$ changes induced}

in apples by apple pathogen $C$. acutatum and non-apple pathogens $C$. gloeosporioides and $C$. coccodes.

C. acutatum decayed Golden Delicious apples. Within 7 days postinoculation, the average lesion diameter was $4.2 \pm$ $0.3 \mathrm{~mm}$. C. gloeosporioides and C. coccodes caused only me-

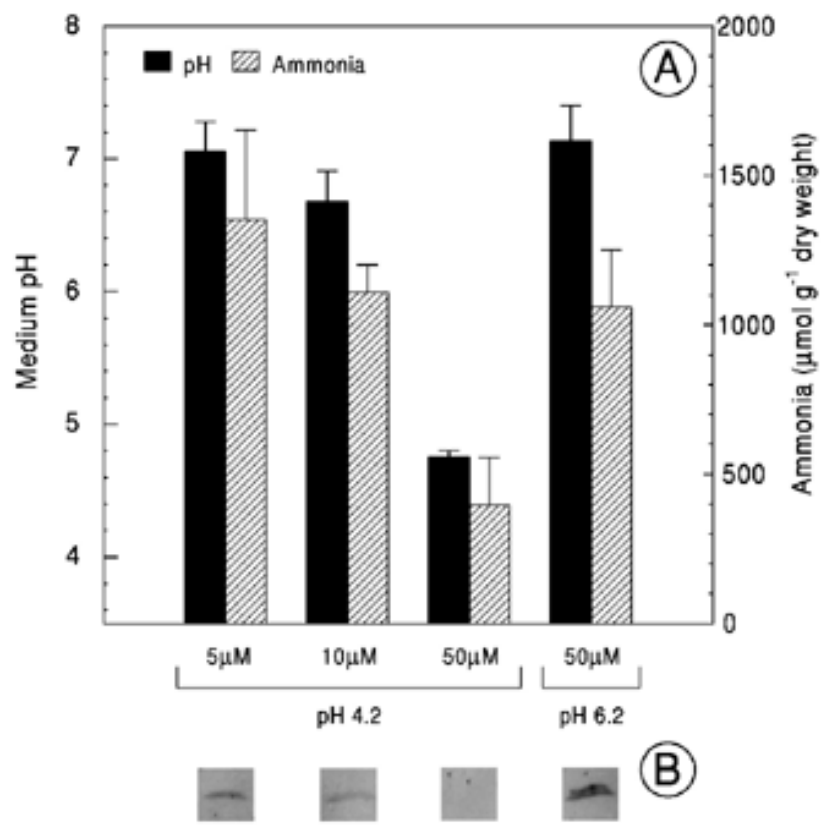

Fig. 4. Effect of pH and buffer molarity on the induction of ammonia accumulation, $\mathrm{pH}$ increase, and pectate lyase (PL) secretion by Colletotrichum gloeosporioides in yeast extract medium. A, Effect of initial medium $\mathrm{pH}$ and buffer molarity on final $\mathrm{pH}$ and ammonia accumulation. B, PL detection by Western blot analysis, following the concentration of growth medium. 
dium and minor lesions, however, with average decay diameters of $1.5 \pm 0.3$ and $0.7 \pm 0.2 \mathrm{~mm}$, respectively.

Direct $\mathrm{pH}$ measurement of decayed apple tissue inoculated with $C$. acutatum indicate a very localized $\mathrm{pH}$ change only in the infected area (Fig. 7). pH measurements of healthy apple tissue (OE and $\mathrm{OH}$ in Fig. 8) had $\mathrm{pH}$ values from 3.9 to 4.1, but in the decayed tissue, the $\mathrm{pH}$ increased to 6.5. Similar $\mathrm{pH}$ values were detected in the center (DC in Fig. 8) or inner edge (DE in Fig. 8) of the decayed tissue. The concentration of ammonia in the healthy part of the apple was $90 \mu \mathrm{M}$, with a $\mathrm{pH}$ value of 3.8 , whereas in the decayed tissue, ammonia concentration increased almost 2.8 -fold $(250 \mu \mathrm{M})$, with a $\mathrm{pH}$ of 6.9 .

$\mathrm{pH}$ values in the decayed tissue of apples inoculated with $C$. gloeosporioides and $C$. coccodes were lower than for $C$. acutatum, reaching only 4.0 to 5.1 (Fig. 8). In the healthy part of the apple, the values were similar to those in apples inoculated with $C$. acutatum. The concentration of ammonia and the $\mathrm{pH}$ in the juice of apples decayed by $C$. gloeosporioides and $C$. coccodes was 80 and $60 \mu \mathrm{M}$, respectively, with a $\mathrm{pH}$ of 4.0 to 5.5. In the healthy tissue, the concentration of ammonia was 50 to $60 \mu \mathrm{M}$, with $\mathrm{pH}$ values of approximately 4.0 to 4.3 .
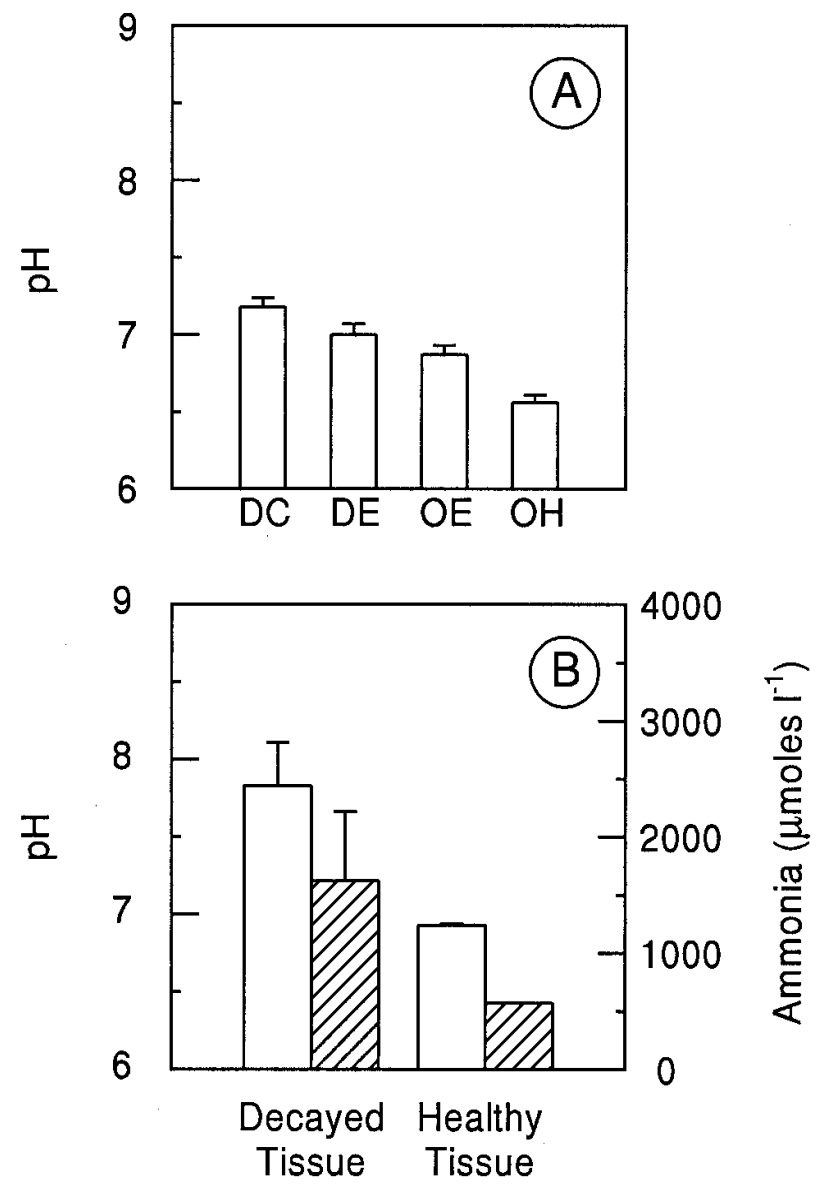

Fig 5. $\mathrm{pH}$ changes and ammonia accumulation induced by Colletotrichum gloeosporioides on avocado fruits cv. Hass. A, Direct $\mathrm{pH}$ measurements. B, $\mathrm{pH}$ and ammonia concentration in the juice of the fruit. $\mathrm{DC}$, decay center; DE, decay edge; $\mathrm{OE}$, outside healthy edge; $\mathrm{OH}$, outside healthy tissue. Measurements were taken 7 days postinoculation. Results are from one of four different experiments.
Enhanced virulence of $C$. acutatum, C. gloeosporioides, and $C$. coccodes by enhanced ammonia production.

Decay development of C. acutatum, C. gloeosporioides, and $C$. coccodes differed significantly on inoculated apples with $C$. acutatum being the most pathogenic, although buffered at pH 7.0 (Fig. 9). Decay development of all Colletotrichum species was enhanced when apples were inoculated with spores of the three species in the presence of $1 \%$ yeast extract or $15 \mu \mathrm{M}$ ammonium chloride at $\mathrm{pH}$ 7.0. Yeast extract and ammonium chloride enhanced decay development of $C$. gloeosporioides on apples to values similar to those produced by the pathogen $C$. acutatum but could not enhance decay development of $C$. coccodes to the same levels as that of $C$. acutatum.

\section{DISCUSSION}

Resistance of unripe avocado fruits to $C$. gloeosporioides depends on the presence of significant concentrations of antifungal compounds (Prusky 1996; Prusky and Keen 1993; Prusky et al. 1988; Simmonds 1941). Yakoby et al. (2000), however, reported that ripe fruits from specific cultivars with
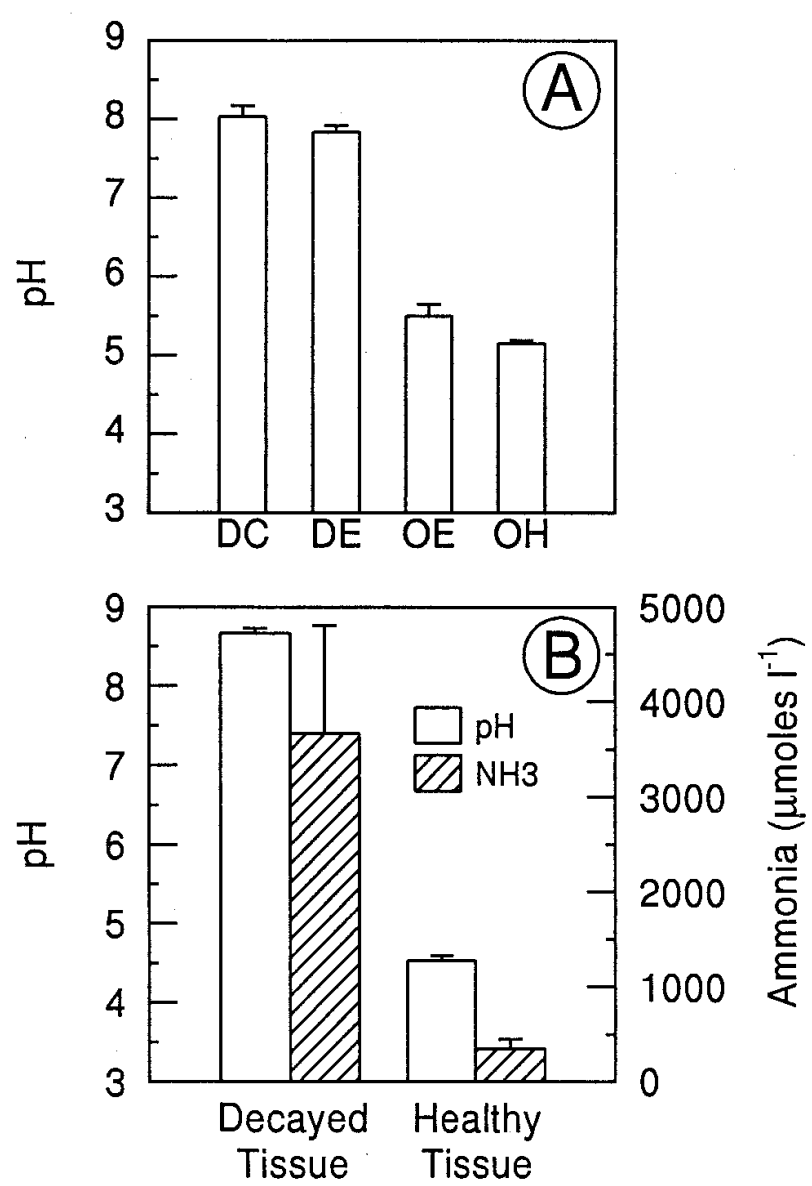

Fig 6. $\mathrm{pH}$ changes and ammonia accumulation induced by Colletotrichum coccodes on tomato cv. Roma fruits. A, Direct $\mathrm{pH}$ measurements. B, pH and ammonia concentration in the juice of the fruit. Measurements were performed 5 days postinoculation. Results are from one of four experiments. DC, decay center; DE, decay edge; OE, outside healthy edge; $\mathrm{OH}$, healthy tissue. 
significantly lower concentrations of the antifungal diene were still resistant to C. gloeosporioides (Prusky 1996). The absence of fungal colonization in fruit pericarp and PL expression at $\mathrm{pH}$ values lower than 5.8 suggested that host environmental regulation of $\mathrm{pH}$ affects $\mathrm{PL}$ secretion and virulence (Prusky 1996). When Colletotrichum species were grown on solid medium containing yeast extract at $\mathrm{pH} 4.2$, the $\mathrm{pH}$ of the colony area increased to values of 7.7 and the area of $\mathrm{pH}$ levels of $>6.0$ expanded out from the colony. Presumably, this indicates that the metabolic activity at the leading hyphal edge of the fungus grown on yeast extract, including oxidative deamination of amino acids, leads to ammonia accumulation, diffusion (Jennings 1989), and a correspondent pH change. Analysis of ammonia levels produced by Colletotrichum species and the $C$. gloeosporioides pelB gene-disrupted mutant in the presence of a concentrated protein source and $\mathrm{pH}$ increase indicates that ammonia was produced during growth at levels sufficient to account for alkalinization of the medium. Ammonia was reported to be produced by several fungi such as $\mathrm{Neu}$ rospora crasa, Aspergillus fumigatus, Metarhizium anisopliae (St. Leger et al. 1998), and Candida albicans (De Bernardis et al. 1998). Ammonia production by fungi during growth on protein as the sole carbon source is believed to result from dissimilation of amino nitrogen produced in excess of that required for growth (Jennings 1989). N. crassa and A. fumigatus, however, also produced ammonia in minimal medium, suggesting that the source may be internal nitrogenous reserves. The production of ammonia by Colletotrichum species and the decay of fruits such as avocado, tomato, and apple suggests that Colletotrichum species efficiently utilize the nitrogen sources present in the fruits.

$\mathrm{pH}$ increases in liquid medium exhibit a two-stage process. During the first stage, an increase of $6,000 \mu \mathrm{mol}$ of ammonia per $\mathrm{g}$ of dry weight of Colletotrichum spp. hyphae increase the $\mathrm{pH}$ in the medium by $1 \mathrm{U}$, whereas in the second stage, only 1,500 $\mu$ mol of ammonia per $g$ of dry weight was needed to increase the $\mathrm{pH}$ in the medium by $1 \mathrm{U}$. This suggests that buffer capacity affects the $\mathrm{pH}$ increase in the medium. The importance of buffer capacity in the medium was shown when the reduction (from 50 to $5 \mu \mathrm{M}$ ) of the concentration of the phthalate buffer, $\mathrm{pH} 4.2$, led to a significant increase in ammonia accumulation. When the fungus was grown in $50 \mu \mathrm{M}$ buffer at $\mathrm{pH} 6.2$, however, rapid ammonia secretion occurred, comparable to $5 \mu \mathrm{M}$ buffer at $\mathrm{pH}$ 4.2. This suggests that low $\mathrm{pH}$ is not a signal for the initiation of ammonia secretion; rather, the combination of a proper $\mathrm{pH}$ and buffer strength regulates ammonia secretion and, consequently, gives an increase in $\mathrm{pH}$.

Previous studies by Yakoby et al. (2000) with avocado fruits indicate that $\mathrm{pH}$ increases in ripening fruits can lead to PL secretion and consequent decay development. In the present report, apples, tomatoes, and avocados with a $\mathrm{pH}$ of 3.5, 4.2, and 6.5 , respectively, had an increase of local $\mathrm{pH}$ to 7.2 or above when inoculated with compatible Colletotrichum spp. pathogens. In all three fruit-pathogen interactions, a significant increase in ammonia concentration also was detected locally in the decayed tissue. The amount of ammonia accumulated in $C$. acutatum-decayed apples was approximately one-tenth $(250 \mu \mathrm{M})$ of that in tomato and avocado. These results suggest that there are different initial levels and, possibly, sources of nitrogen in each fruit, which also may contribute to the presence of different $\mathrm{pH}$ values in healthy fruit
(Hulme 1970). It may be possible that the higher initial $\mathrm{pH}$ values of avocado and tomato enable the fungus to grow rapidly and produce more ammonia, similar to the growth in liquid medium at higher $\mathrm{pH}$. In nonhost interactions where $C$. gloeosporioides and C. coccodes caused only reduced or minor infections on apples, the ammonia levels in infected tissue were similar to those in the healthy part of the fruit.

It is difficult to conclude that ammonia production directly enhances the pathogenicity of Colletotrichum species because it affects virulence by increasing the environmental $\mathrm{pH}$ needed for full pathogenicity. It is clear, however, that pelB expression is not dependent on the secretion and accumulation of ammonia because PL was not produced when the mutant was grown in media-inducing ammonia formation (Yakoby et al. 2001). When ammonia-inducing or -releasing compounds were added to the infection point, however, colonization by $C$. gloeosporioides (a nonhost pathogen in apples) increased in a similar manner as the compatible $C$. acutatum. This effect did not occur when ammonia-inducing compounds were added to C. coccodes spores before apple inoculation, suggesting that factors other than the presence of ammonia may be necessary to enhance decay development of $C$. coccodes in apples. In a bacterial system, an increase in intercellular $\mathrm{pH}$ from 5.5 to 7.5 was found when Pseudomonas syringae pathovars infected Phaseolus vulgaris. This $\mathrm{pH}$ change appears to promote bacterial population growth. In this case, sucrose efflux was suggested as the causal factor for bacterial growth. It should be noted that the effect of nitrogen-containing compounds on the $\mathrm{pH}$ change in this bacterial system was not investigated (Atkinson and Baker 1987).

The importance of $\mathrm{pH}$-responsive gene regulation during pathogen attack was not always considered a pathogenicity factor. Rollins and Dickman (2001) and earlier work suggests that pathogenicity of Sclerotinia sclerotiorum is regu-

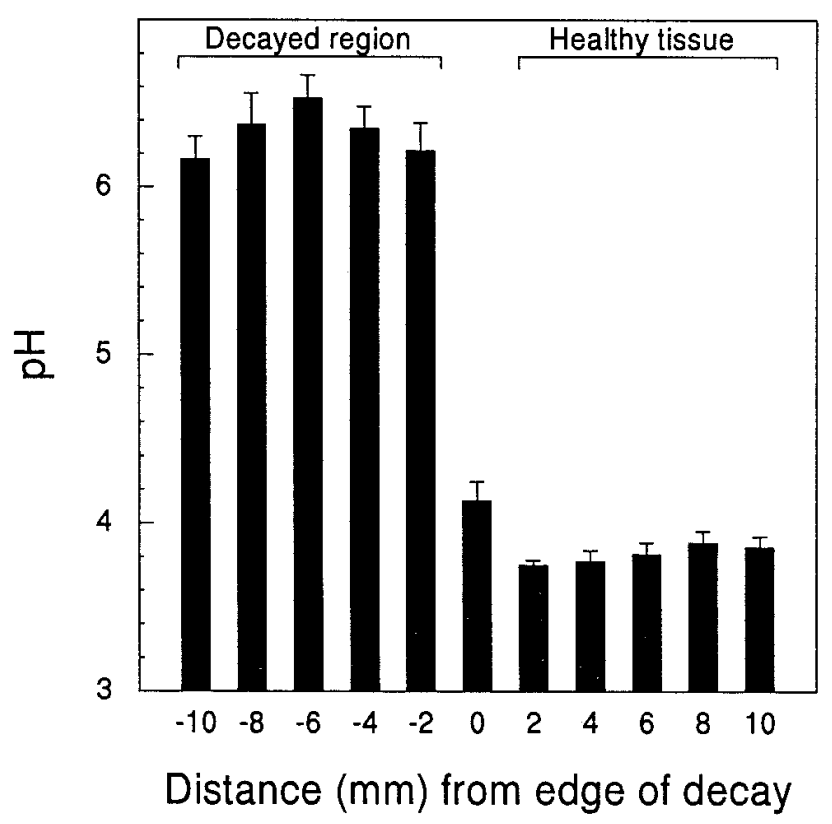

Fig. 7. $\mathrm{pH}$ changes induced by Colletotrichum acutatum on Golden Delicious apples. Direct $\mathrm{pH}$ measurements on decayed and healthy tissues were taken 10 days postinoculation when the decay diameter was $20 \mathrm{~mm}$. Results are from one of five experiments conducted. 
lated by the acidification of the environment as a result of oxalic acid secretion, which is necessary for the activity of polygalacturonases. These enzymes have been implicated as colonization and virulence factors in other plant-infecting fungi (Shieh et al. 1997; Ten Have et al. 1998). The present results, however, are what we believe to be the first report where local alkalinization, as a result of ammonia increase, is suggested to be a virulence factor. The ability of Colletotrichum spp. to modify the $\mathrm{pH}$ at the infection site results in enhanced virulence because ammonia secretion and the resulting $\mathrm{pH}$ increase leads to higher pelB expression and $\mathrm{PL}$ secretion (Yakoby et al. 2000). The finding that the $C$. gloeosporioides pelB gene-disrupted mutant produces amounts of ammonia similar to the wild-type C. gloeosporioides suggests that ammonia accumulation is independent of pelB expression. By secreting ammonia, the fungus ensures that PL is produced under optimal $\mathrm{pH}$ conditions because the protein has an apparent $\mathrm{pH}$ optimum of 8.9 (Wattad et al. 1994). The present results further emphasize the importance of PL secretion for pathogenicity because $p g$ transcripts and PG protein secretion by $C$. gloeosporioides occurs at a lower $\mathrm{pH}$ (5.0). Activity of the PG protein has an optimum $\mathrm{pH}$ of 5.1, a condition under which avocado fruits are not susceptible (Prusky et al. 1989; Yakoby et al. 2000; Yakoby et al. 2001).
The $\mathrm{pH}$ effect on pelB expression suggests that an ambient $\mathrm{pH}$ signal transduction pathway exists in $C$. gloeosporioides. Such a pathway has been characterized in Aspergillus nidulans and $S$. sclerotiorum, and several components of this pathway, including the $\mathrm{pH}$-dependent transcription regulator $p a c \mathrm{C}$, have been cloned and characterized (Rollins and Dickman 2001; Tilburn et al. 1995). The conservation of the zinc finger region among the various fungal homologs (Espeso et al. 1997; MacCabe et al. 1996; Suarez and Penalva, 1996) and the central role, which PacC plays in mediating the $\mathrm{pH}$-dependent signaling, make the pacC gene an important gene for future testing during ambient $\mathrm{pH}$ induction of $p e l \mathrm{~B}$ expression and $\mathrm{PL}$ secretion of $C$. gloeosporioides.

Fungi can use a surprisingly diverse array of compounds as nitrogen sources and are capable of expressing, upon demand, the catabolic enzymes of many different pathways (Marzluf 1997). Few reports have suggested a relationship between nitrogen metabolic regulation and fungal pathogenesis. Nutritional limitations of various types, particularly nitrogen deprivation, appears to have a link to pathogenesis and other fungal morphogenetic switches (Lau and Hamer 1996; Talbot et al. 1993). Our results indicate that the accumulation of ammonia affects fungal attack. These findings, however, do not exclude that other factors such as nitrogen metabolism or the utiliza-

\section{C. acutatum \\ C. coccodes \\ C. gloeosporioides}

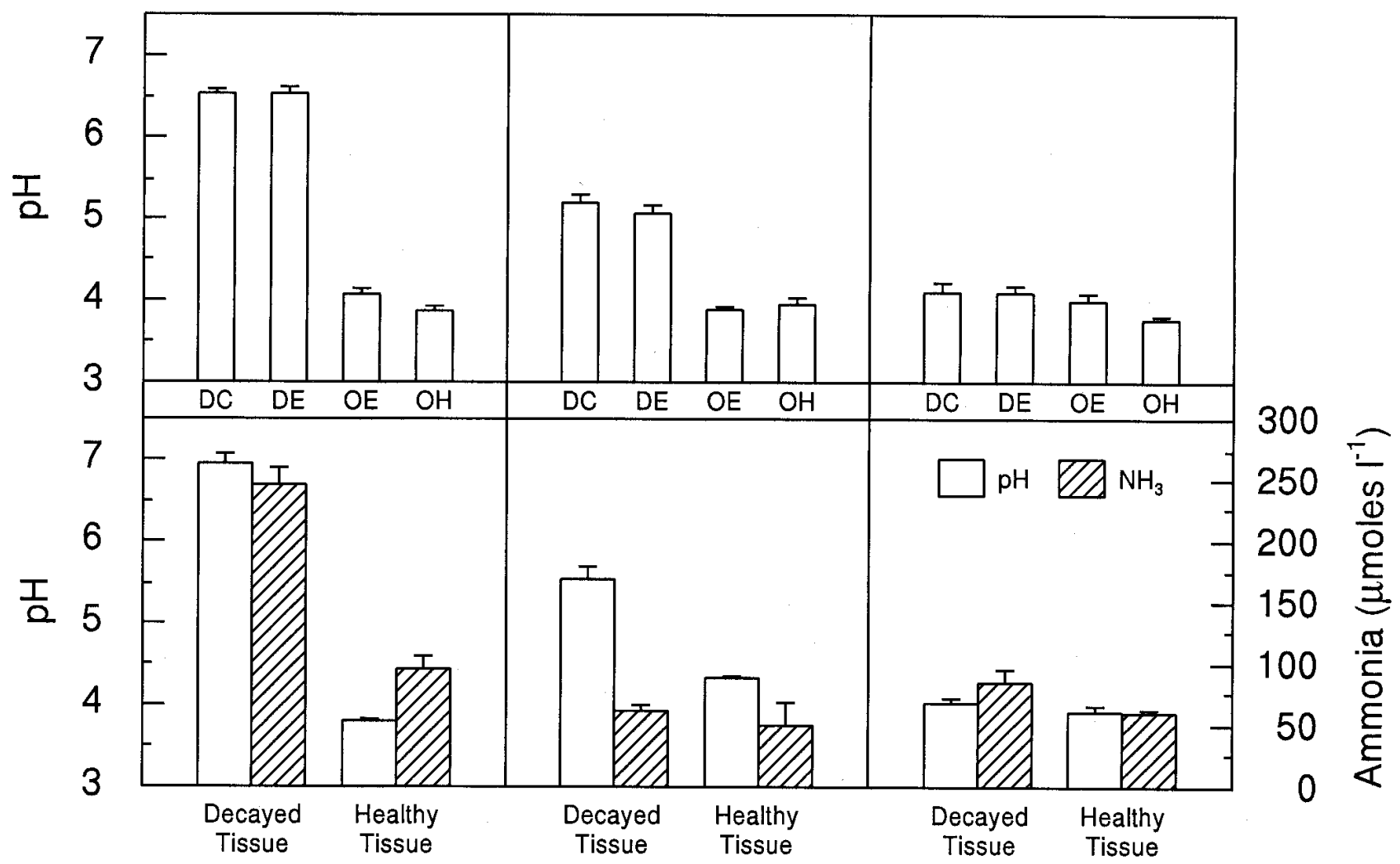

Fig. 8. $\mathrm{pH}$ changes and ammonia accumulation induced by Colletotrichum acutatum, Colletotrichum gloeosporioides, and Colletotrichum coccodes on Golden Delicious apples. A, Direct pH measurements. B, pH and ammonia concentration of the juice of the fruit. Measurements were performed 6-7 days postinoculation. Results are from one of five experiments conducted. DC, decay center; DE, decay edge; OE, outside healthy edge; OH, outside healthy tissue. 
tion of host organic acid by the fungus may play a role in the increase of host $\mathrm{pH}$. The activation of PL secretion, as a result of ammonia accumulation and elevated $\mathrm{pH}$, seems to be a newly described mechanism through which nitrogen metabolism can affect pathogenicity. Because this mechanism was in three different hosts and occurred during the decay by three different Colletotrichum species, the effect of environmental $\mathrm{pH}$ modulation may have broad significance and could be used in plant-breeding programs to control decay occurring in other postharvest pathosystems.

\section{MATERIALS AND METHODS}

\section{Strains, media, and growth conditions.}

C. acutatum was isolated from decayed apples, $C$. coccodes from isolated decayed tomato, and $C$. gloeosporioides isolate Cg-14 was obtained from decayed avocado fruit. The $C$. gloeosporioides pelB gene-disrupted mutant was developed by Yakoby et al. (2001). Single-spore cultures were prepared from each isolate, and spores were stored in $10 \mathrm{mM} \mathrm{Na}$ phosphate buffer ( $\mathrm{pH} \mathrm{7.2)} \mathrm{and} 40 \%$ glycerol, at $-80^{\circ} \mathrm{C}$.

Spores taken from 10- to 20-day-old cultures were harvested from $\mathrm{M}_{3} \mathrm{~S}$ medium ( $\mathrm{Tu}$ 1985). Erlenmeyer flasks $(150 \mathrm{ml})$ containing $50 \mathrm{ml}$ of medium, with $1 \%$ yeast extract (Sigma, St. Louis, MO, U.S.A.), at $\mathrm{pH} 4.0$, were inoculated with the $C$. acutatum and $\mathrm{Cg}$-14 isolates $\left(1.0 \times 10^{6}\right.$ spores per flask) and grown at $25^{\circ} \mathrm{C}$ on an orbital shaker (150 rpm). The resulting mycelium subsequently was filtered through Whatman No. 1 filter paper (Clifton, NJ, U.S.A.) and dried for 2 days at $40^{\circ} \mathrm{C}$, prior to weighing. In vitro experiments were repeated four times. The results of one representative experiment are presented.

\section{Fruits, inoculation conditions, and statistical analysis.}

Golden Delicious apples were harvested in the preclimacteric stage and stored at $0^{\circ} \mathrm{C}$ for 2 to 3 months until used for experiments. Tomato fruit Lycopersicum esculentum cv. Roma and avocado fruits Persea americana cv. drymifolia cv. Hass were bought in a local supermarket.

Inoculation was carried out by wounding the fruits to a depth of 2 to $3 \mathrm{~mm}$ and placing $30 \mu \mathrm{l}$ of spore suspension $\left(10^{6}\right.$ spores per $\mathrm{ml}$ ) at four points, two on each side of the longitudinal axis, of 15 fruits. The fruits were then incubated at $20^{\circ} \mathrm{C}$, in $90 \%$ humidity, for 5 to 10 days. In some experiments, the inoculation medium was adjusted, to $\mathrm{pH} 6.2$ and 4.2, with phthalate buffer of different molar concentrations.

In vivo experiments were repeated at least three times. The results of one representative experiment are presented. Standard errors of the means were calculated.

\section{pH measurements.}

$\mathrm{pH}$ was measured with a micro-combination $\mathrm{pH}$ electrode, Model 9810BN (Orion, Beverly, MA, U.S.A.), in 1- to 3-ml aliquots, sampled at different times after fungal inoculation. Pericarp $\mathrm{pH}$ was determined following a transverse cut through the infection site with a scalpel blade. $\mathrm{pH}$ measurements were taken by placing the micro $\mathrm{pH}$ electrode directly against the exposed tissue. The electrode can measure $\mathrm{pH}$ in a gel thickness of less than $1.5 \mathrm{~mm}$. All measurements were repeated on 10 to 12 fruits at three different points (at least 30 measurements) on the transverse axis of the infection on each fruit. The standard errors of the means of $\mathrm{pH}$ measurements were never higher than $2.5 \%$. To test the hypothesis that direct $\mathrm{pH}$ measurement is a reliable indicator of the environment within the fruit, the direct measurement was compared with the $\mathrm{pH}$ determined by the common homogenization method (Lurie and Pesis 1992) in which 2 to $4 \mathrm{~g}$ of pericarp tissue was crushed with a plunger and filtered through a 4-ml, 0.45- $\mu \mathrm{m}$ centrifuge filter (Eppendorf Scientific, Westbury, NY, U.S.A.) at $4,000 \times g$. Direct and homogenate $\mathrm{pH}$ measurements were compared in all fruits used in the present work (30 measurements). The regression coefficient between the measurements was $r=0.999$. $\mathrm{pH}$ also was evaluated with a $\mathrm{pH}$ indicator, Alizarin red S (Sigma), which shows red at a $\mathrm{pH}$ higher than 6.0 and yellow at $\mathrm{pH}$ values of 4.0 and less.

\section{Detection of ammonia in the liquid media and in the tissue.}

Ammonia concentration was determined in filtered culture medium or tissue homogenate. Ammonia was measured with an ammonia electrode, Model 95-12 (Orion), in 0.1- to 1-ml aliquots (depending upon the concentration), at $\mathrm{pH}$ 10.0, sampled at different times after inoculation. Different concentrations ( 7 to $700 \mu \mathrm{M}$ ) of $\mathrm{NH}_{4} \mathrm{Cl}$ were used as standards. Experiments with three replications were repeated at least three times. The results of one representative experiment are presented. Standard errors of the means were calculated.

\section{PL in liquid medium.}

C. gloeosporioides hyphae was separated from the culture medium by centrifugation $(12,000 \times g$ for $10 \mathrm{~min})$, at $4^{\circ} \mathrm{C}$.

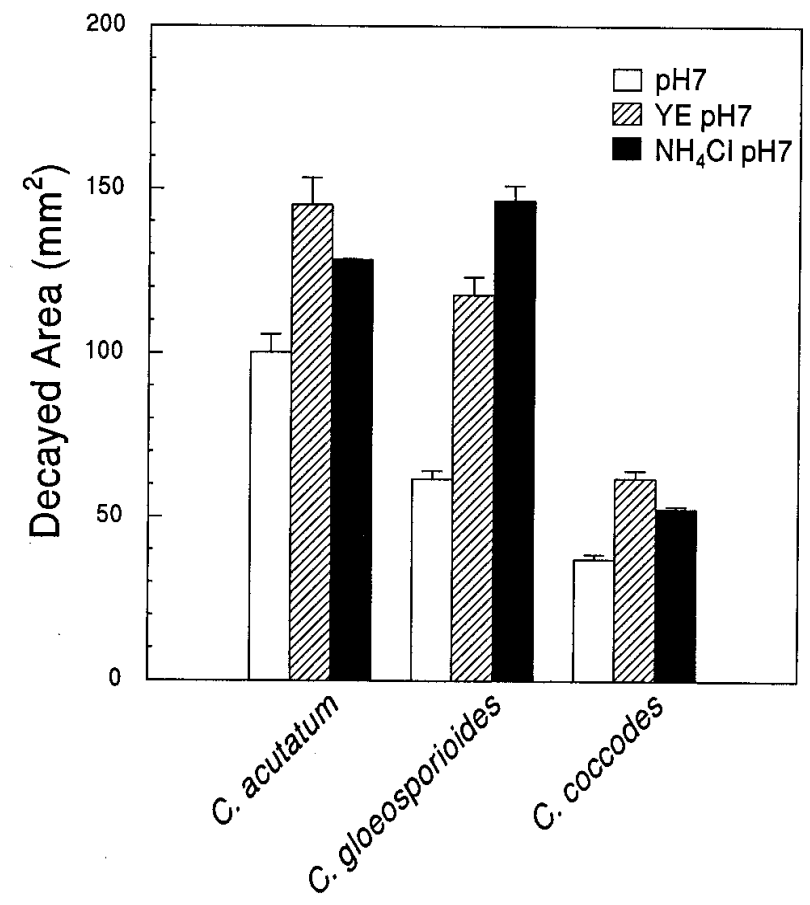

Fig 9. Enhancement of virulence of Colletotrichum species by ammonia releasing compounds in apple fruit cultivars Golden Delicious. Spores of Colletotrichum gloeosporioides, Colletotrichum acutatum, and Colletotrichum coccodes suspended in $0.05 \mathrm{M}$ phthalate $\mathrm{pH} 7$ or in the same buffer containing $1 \%$ yeast extract or $15 \mathrm{mM}$ ammonium chloride. Spore suspension $\left(50 \mu \mathrm{l} ; 10^{6}\right.$ spores per $\left.\mathrm{ml}\right)$ in the different solutions was applied to the wounded apples. 
The culture medium supernatant $(50 \mathrm{ml})$ was freeze-dried and diluted in $5 \mathrm{ml}$ of distilled water. The concentrated culture filtrate (Sigma) was dialyzed overnight (cut off at molecular weight of 6,000) against 2 liters of $50 \mathrm{mM}$ Tris- $\mathrm{HCl}, \mathrm{pH} 8.5$, concentrated to $5 \mathrm{ml}$, as above; $5 \mu \mathrm{g}$ per lane were used for Western blot analysis.

Each protein sample was quantified with Protein Assay (Bio-Rad Laboratories, Hercules, CA, U.S.A.), with bovine serum albumin as the standard. Samples were boiled for $4 \mathrm{~min}$ in loading buffer, according to Sambrook et al. (1989), with $10 \% \beta$-mercaptoethanol as a reducing agent. Samples were then loaded onto a $12.5 \%$ sodium dodecyl sulfatepolyacrylamide gel (Mini-Protean II; Bio-Rad Laboratories) and run for $1 \mathrm{~h}$ at a constant $150 \mathrm{~V}$. Western blot analysis was performed with PL antibodies diluted to 1:500 (Wattad et al. 1997). Preimmune ascetic fluid was used as a control, and anti-mouse immunoglobulin $\mathrm{G}$ (IgG) alkaline phosphatase (AP) conjugate (Promega, Madison, WI, U.S.A.) was used as a secondary antibody. Nonimmune serum was used as a control. Anti-rabbit IgG AP conjugate was used as the secondary antibody. Both secondary antibodies were used at a dilution of $1: 6,000$.

\section{ACKNOWLEDGMENTS}

We thank N. T Keen and J. Baker for reviewing the manuscript and suggesting changes.

\section{LITERATURE CITED}

Atkinson, M. M., and Baker, C. J. 1987. Alteration of plasmalemma sucrose transport in Phaseolus vulgaris by Pseudomonas syringae pv. syringae and its association with the $\mathrm{K}^{+} / \mathrm{H}^{+}$exchange. Phytopathology 77:1573-1578.

Benhamou, N. 1996. Elicitor-induced plant defence pathways. Trends Plant Sci. 1:233-240.

De Benardis, F., Muhlschledgel, F. A., Cassone, A., and Fonzi, W. A 1998. The $\mathrm{pH}$ of the host niche controls gene expression and virulence of Candida albicans. Infect. Immun. 66:3317-3325.

Denison, S. H. 2000. pH regulation of gene expression in fungi. Fungal Genet. Biol. 29:61-71.

Espeso, A. E., Tilburn, J., Arst, N. H., and Penalva, A. M. 1993. pH regulation is a major determinant in expression of a fungal penicillin biosynthetic gene. EMBO J. 12:3947-3956.

Espeso, A. E., Tilburn, J., Sanchez-Pulido, L., Brown, C. V., Valencia, A., Arst, N. H., and Penalva, A. M. 1997. Specific DNA recognition by the Aspergillus nidulans three zinc finger transcription factor PacC. J. Mol. Biol. 274:466-480.

Keller, N. P., Nesbitt, C., Sarr, B., Phillips, T. D., and Burow, G. B. 1997. $\mathrm{pH}$ regulation of sterigmatocystin and aflatoxin biosynthesis in Aspergillus spp. Phytopathology 87:643-648.

Jennings, D. H. 1989. Some perspectives on nitrogen and phosphorous metabolism in fungi. Pages 1-31 in: Nitrogen, Phosphorous and Sulphur Utilization by Fungi. L. Boddy, R. Marchant, and D. J. Read, eds. Cambridge University Press, Cambridge, U.K.

Lau, G., and Hamer, J. E. 1996. Regulatory genes controlling MPG1 expression and pathogenicity in the rice blast fungus Magnaporthe grisea. Plant Cell 8:771-781.

Lurie, S., and Pesis, E. 1992. Effect of acetaldehyde and anaerobiosis as postharvest treatments on the quality of peaches and nectarines. Postharvest Biol. Technol. 1:317-326.

MacCabe, A. P., Van den Hombergh, J. P. T. W., Tilburn, J., Arst, H. N., Jr., and Visser, J. 1996. Identification, cloning and analysis of the Aspergillus niger gene pac $\mathrm{C}$, a wide domain regulatory gene responsive to ambient pH. Mol. Gen. Genet. 250:367-374.

Maccheroni, W., Jr., May, S. G., Martinez-Rossi, M. N., and Rossi, A.
1997. The sequence of $p a l \mathrm{~F}$, an environmental $\mathrm{pH}$ response gene in Aspergillus nidulans. Gene 194:163-167.

Marzluf, G. A. 2997. Genetic regulation of nitrogen metabolism in the fungi. Microbiol. Mol. Biol. Rev. 62:17-32.

Muhlschlegel, A. F., and Fonzi, A. W. 1997. PHR2 of Candida albicans encodes a functional homologue of the $\mathrm{pH}$-regulated gene PHR1 with an inverted pattern of $\mathrm{pH}$-dependent expression. Mol. Cell. Biol. 17:5960-5967.

Orejas, M., Espeso, A. E., Tilburn, J., Sarkar, S., Arst, N. H., Jr., and Penalva, A. M. 1995. Activation of the Aspergillus PacC transcription factor in response to alkaline ambient $\mathrm{pH}$ requires proteolysis of the carboxyl-terminal moiety. Gen. Dev. 9:1622-1632.

Otero, C. R., and Gaillardin, C. 1996. Dominant mutation affecting expression of $\mathrm{pH}$-regulated genes in Yarrowia lipolytica. Gen. Genet. 252:311-319.

Prusky, D. 1996. Pathogen quiescence in postharvest diseases. Annu. Rev. Phytopathol. 34:413-434.

Prusky, D., and Keen, N. T. 1993. Involvement of preformed antifungal compounds in the resistance of subtropical fruits to fungal decay. Plant Dis. 77:114-119.

Prusky, D., Kobiler, I., and Jacoby, B. 1988. Involvement of epicatechin in cultivar susceptibility of avocado fruits to Colletotrichum gloeosporioides after harvest. Phytopathol. Z. 123:140-146.

Prusky, D., Gold, S., and Keen, N. T. 1989. Purification and characterization of an endopolygalacturonase produced by Colletotrichum gloeosporioides. Physiol. Mol. Plant Pathol. 35:121-133.

Rollins, J. A., and Dickman, M. B. 2001. pH signaling in Sclerotinia sclerotiorum: Identification of pacC/RIM1 homolog. Appl. Environ. Microbiol. 67:75-81.

St. Leger, J. R., Joshi, L., and Roberts, D. 1998. Ambient pH is a major determinant in the expression of cuticle-degrading enzymes and hydrophobin by Metarhizium anisopliae. Appl. Environ. Microbiol. 64:709-713.

St. Leger, J. R., Nelson, J. O., and Screen, S. E. 1999. The entomopathogenic fungus Metarhizium anisopliae alter ambient $\mathrm{pH}$, allowing extracellular protease production and activity. J. Microbiol. 145:2691-2699.

Sambrook, J., Fritsch, F. E., and Maniatis, T. 1989. Molecular Cloning: A Laboratory Manual, 2nd ed. Cold Spring Harbor Laboratory, Cold Spring Harbor, NY, U.S.A.

Shieh, M., Brown, R. L., Whitehead, M. P., Carey, J. W., Cotty, P. J., Cleveland, T. E., and Dean, R. 1997. Molecular genetic evidence for the involvement of a specific polygalacturonase, $\mathrm{P} 2 \mathrm{c}$, in the invasion of Aspergillus flavus in cotton balls. Appl. Environ. Microbiol. 63:3548-3552.

Simmonds, J. H. 1941. Latent infection in tropical fruits discussed in relation to part played by species of Gloeosporium and Colletotrichum. Proc. R. Soc. Queensl. 52:92-120.

Suarez, T., and Penalva, M. A. 1996. Characterization of a Penicillium chrysogenum gene encoding a PacC transcription factor and its binding sites in the divergent $p c b \mathrm{AB}-p c b \mathrm{C}$ promoter of the penicillin biosynthetic cluster. Mol. Microbiol. 20:529-540.

Talbot, N. J., Ebbole, D. J., and Hamer, J. E. 1993. Identification and characterization of MPG1, a gee involved in pathogenicity from the rice blast fungus Magnaporthe grisea. Plant Cell 5:1575-1590.

Ten Have, A., Mulder, W., Visser, J., and Van Kan, J. A. L. 1998. The endopolygalacturonase gene Bcpg1 is required for full virulence of Botrytis cinerea. Mol. Plant-Microbe Interact. 11:1009-1016.

Tilburn, J., Sarkar, S, Widdick, D. A., Espeso, E. A, Orejas, M., Mungroo, J., Penalva, M. A. Arst, N. H., Jr. 1995. The Aspergillus PacC zinc finger transcription factor mediates regulation of both acidic- and alkaline-expressed genes by ambient pH. EMBO J. 14:770-700.

Tu, J. C. 1985. An improved mathur's medium for growth, sporulation and germination of spores of Colletotrichum lindemuthianum. Microbiosis 44:87-93.

Wattad, C., Dinoor, A., and Prusky, D. 1994. Purification of pectate lyase produced by Colletotrichum gloeosporioides and its inhibition by epicatechin: A possible factor involved in the resistance of unripe avocado fruits to anthracnose. Mol. Plant-Microbe Interact. 7:293-297.

Wattad, C., Kobiler, D., Dinoor, A., and Prusky, D. 1997. Pectate lyase of Colletotrichum gloeosporioides attacking avocado fruits: cDNA cloning and involvement in pathogenicity. Physiol. Mol. 
Plant Pathol. 50:197-212.

Yakoby, N., Kobiler, I., Dinoor, A., and Prusky D. 2000. pH regulation of pectate lyase secretion modulates the attack of Colletotrichum gloeosporioides on avocado fruits Appl. Environ. Microbiol. 66:1026-1030.
Yakoby, N., Beno-Moualem, D., Keen, N. T., Dinoor, A., Pines, O, and Prusky, D. 2001. Colletotrichum gloeosporioides pelB is an important virulence factor in avocado fruit-fungus interaction. Mol. Plant-Microbe Interact. 14:988-995. 